\title{
Baanonzekerheid, welzijn en gezondheid
}

\author{
Tanja de Jong, Noortje Wiezer en Catelijne Joling*
}

\begin{abstract}
In dit artikel wordt een antwoord gegeven op de volgende vragen: (I) Worden negatieve effecten van tijdelijke contracten op welzijn en gezondheid vooral veroorzaakt door de baanonzekerheid die werknemers met een alternatief contract ervaren? En (2) Veranderen effecten van baanonzekerheid als werknemers minder belang hechten aan baanzekerheid? Voor de analyses zijn data van de TNO Arbeidssituatie Survey uit 2004 gebruikt. De resultaten, gebaseerd op meervoudige-regressieanalyse, laten zien dat werknemers met een tijdelijk contract inderdaad meer burn-outklachten ervaren, een minder goede gezondheid ervaren en minder tevreden zijn met de organisatie en het werk dan werknemers met een vast contract. Dit verschil wordt voor een deel verklaard door de grotere baanonzekerheid die werknemers met een tijdelijk contract ervaren. Het belang dat werknemers hechten aan baanzekerheid is vooral relevant als het effect van baanonzekerheid op ervaren burn-outklachten wordt beschouwd. De stress die baanonzekerheid met zich meebrengt, wordt hoger naarmate werknemers meer belang hechten aan baanzekerheid. Vooral werknemers met een laag opleidingsniveau hechten veel belang aan baanzekerheid. Steeds minder organisaties garanderen baanzekerheid voor werknemers. Het is daarom belangrijk om de 'employability' van werknemers te versterken.
\end{abstract}

Trefwoorden: tijdelijke contracten, baanonzekerheid, welzijn, belang baanzekerheid

\section{Inleiding}

De organisatie van de arbeid is gedurende de twintigste eeuw sterk veranderd (Boxall \& Purcell, 2007; Sparks et al., 2001). Om de concurrentiekracht te behouden hebben organisaties een meer flexibele houding aangenomen. Bedrijven passen steeds vaker en sneller de kwaliteit en kwantiteit van hun personeel aan aan nieuwe eisen die een veranderende markt stelt. Goudswaard et al. (2000) noemen dit 'flexibilisering van de arbeid'. Voor het aanpassen van de kwantiteit van het personeel wordt gebruikgemaakt van flexibele contractvormen, zoals tijdelijke contracten, uitzendcontracten, oproepcontracten, freelancers en zelfstandigen. Deze vorm van flexibilisering wordt ook wel contractflexibiliteit genoemd. Het percentage werknemers met een tijdelijk contract is sinds 1990 meer dan verdubbeld in Nederland. In 1990 had ruim 7\% van de Nederlandse werknemers een tijdelijk contract, in 2006 ligt dit percentage op ruim 16\% (OECD, 2007). Dit percentage is iets hoger dan het gemiddelde van de Europese Unie, dat op $15 \%$ ligt (OECD, 2007). Bovendien is het einde van de flexibilisering nog niet in zicht. Een van de belangrijkste conclusies van een grootschalig onderzoek van TNO naar de toekomst van flexibele arbeid is dat Nederlandse bedrijven de grenzen van hun flexibiliteit nog niet hebben bereikt (Goudswaard et al., 2008). Voor een deel zullen bedrijven andere vormen van flexibiliteit gaan ontwikkelen, maar ook het percentage werknemers met een flexibel contract zal naar verwachting groeien.

* Tanja de Jong is werkzaam bij TNO Kwaliteit van Leven | Arbeid, Postbus 718, 2130 AS Hoofddorp. E-mail: Tanja.deJong@tno.nl.

Noortje Wiezer is werkzaam bij TNO Kwaliteit van Leven | Arbeid.

Catelijne Joling is werkzaam bij TNO Kwaliteit van Leven | Arbeid. 
Terwijl werkgevers baat lijken te hebben bij contractflexibilisering - zij kunnen immers beter en sneller voldoen aan vragen in de markt - is contractflexibilisering voor werknemers niet per definitie positief. Onderzoek wijst uit dat werknemers met een alternatief contract (dat wil zeggen: anders dan een vast contract) een hogere mate van baanonzekerheid ervaren (EASHW, 2007). Ander onderzoek laat zien dat baanonzekerheid op haar beurt een negatief effect kan hebben op baantevredenheid, betrokkenheid en gezondheid van werknemers (Sverke et al., 2002).

Anderzijds zijn bedrijven maar ook werknemers door toenemende flexibilisering meer gewend geraakt aan contractflexibilisering. Weinig werkgevers bieden nog 'een baan voor het leven' en veel werknemers verwachten dat ook niet meer. Met andere woorden: het belang dat gehecht wordt aan baanzekerheid is aan het veranderen. Er zijn mensen die de voorkeur geven aan een tijdelijk contract wegens persoonlijke of gezondheidsredenen (Tucker, 2002) of omdat tijdelijke contracten de mogelijkheid creëren om de eigen carrière te managen en bijvoorbeeld reizen af te wisselen met werken, zo blijkt uit onderzoek onder jongeren (Smithson \& Lewis, 2000). Deze groepen hechten dus minder belang aan baanzekerheid. Recent onderzoek van Huiskamp \& Schalk (2002) toont aan dat baanzekerheid als relatief weinig belangrijk wordt ervaren door werknemers. Dit is een indicatie dat op dit moment werknemers al minder belang hechten aan baanzekerheid. Ook een onderzoek onder uitzendkrachten wijst uit dat de uitzendkracht een uitzendbaan niet als springplank of als bijbaan gebruikt, maar bewust kiest voor de vrijheid die uitzendwerk biedt (ABU, 2007). Uit onderzoek van Eurostat blijkt dat in 2005 in Europa de meerderheid van de werknemers vrijwillig kiest voor een tijdelijk contract. Van de vrouwen is nog slechts 7,5\% onvrijwillig werkzaam in een tijdelijk contract, van de mannen is dit $6,7 \%$ (Hardarson, 2007).

Tijdelijke contracten worden dus steeds gebruikelijker en werknemers lijken hun verwachtingen ten aanzien van baanzekerheid bij te stellen. Dat roept de vraag op of het (mogelijke) negatieve effect van tijdelijke contracten minder groot wordt als deze contracten eerder regel dan uitzondering zijn. Deze vraag kunnen wij niet beantwoorden in de huidige studie. Wel kunnen we nagaan of het belang dat mensen hechten aan baanzekerheid het effect van baanonzekerheid op de gezondheid beïnvloedt. Als dat zo is en ervan uitgaande dat dit belang aan het veranderen is, zou dat betekenen dat negatieve effecten van tijdelijke contracten op de gezondheid van werknemers minder groot worden.

Dit artikel heeft twee doelen. In de eerste plaats onderzoeken we wat de effecten zijn van tijdelijke contracten op tevredenheid, welzijn en gezondheid en in hoeverre deze effecten lopen via de baanonzekerheid die mensen ervaren. Ten tweede gaan we na of het belang dat mensen hechten aan baanzekerheid de relatie tussen baanonzekerheid en tevredenheid, welzijn en gezondheid beïnvloedt. Op deze manier kunnen we onderzoeken of negatieve effecten van baanonzekerheid groter kunnen zijn voor mensen die meer belang hechten aan baanzekerheid. 


\section{Theorie}

\section{Baanonzekerheid}

In de literatuur worden verschillende definities voor baanonzekerheid gehanteerd. De meeste onderzoekers gebruiken een globale definitie en beschrijven baanonzekerheid als 'een algemene bezorgdheid over het voortbestaan van de huidige baan in de toekomst' (Sverke et al., 2002), of de 'ervaren kans op het verlies van de huidige baan' en/ of 'de angst voor het verlies van de huidige baan' (Klein Hesselink \& Van Vuuren, 1999; EASHW, 2007). Het gaat in deze definitie om de perceptie van respondenten over de onzekerheid van de baan. In de literatuur wordt dit ook wel kwantitatieve baanonzekerheid genoemd (Van Gucht \& De Witte, 2006). Vooral voor onderzoek naar de effecten van baanonzekerheid is het belangrijk deze perceptie te onderscheiden van feitelijke baanonzekerheid (bijvoorbeeld als gevolg van een tijdelijk contract of aangekondigde reorganisatie). Respondenten in dezelfde situatie kunnen immers de mate van baanonzekerheid heel verschillend ervaren (Sverke et al., 2002; Strazdins et al., 2004). Overigens gaat objectieve baanonzekerheid vaak samen met subjectieve baanonzekerheid (Klein Hesselink \& Van Vuuren, 1999). Er wordt in de literatuur ook een duidelijk onderscheid gemaakt tussen baanonzekerheid en daadwerkelijk verlies van de baan. Hoewel verlies van een baan en werkloosheid bijzonder stressvolle ervaringen kunnen zijn, mist in deze situaties in ieder geval één stressvolle component: de onzekerheid over het behoud van de baan. Ook dit onderscheid onderstreept nog een keer het belang van onzekerheid (en de mate waarin een respondent dit ervaart) (Jacobson, 1999). Naast contractvormen zijn ook andere factoren van invloed op de ervaren baanonzekerheid. Longitudinaal onderzoek in een aantal Finse organisaties laat zien dat veranderingen in de financiële situatie van de afgelopen jaren (vastgesteld op basis van financiële gegevens van organisaties) een belangrijke voorspeller zijn van baanonzekerheid (Kinunnen et al., 1999). Daarnaast zijn de concurrentiepositie van een bedrijf en de kans op inkrimping als gevolg van bezuinigingen (Cheng, 2005), de kans op reorganisatie met ontslag (Ashford et al., 1989), recente reorganisaties of herstructureringen (Van Gucht \& De Witte, 2006) en de conjunctuur (Kinnunen et al., 1999; Mauno \& Kinnunen, 2002; Bakhuys Roozeboom et al., 2007) voorspellers voor ervaren baanonzekerheid. Ook werknemers die een reorganisatie met ontslagen hebben 'overleefd', zijn nog jaren onzekerder over hun baan dan andere werknemers.

\section{Effecten van baanonzekerheid op tevredenheid, welzijn en gezondheid}

In veel onderzoeken wordt een relatie gevonden tussen baanonzekerheid en attitudes ten aanzien van het werk en de organisatie en de gezondheid van werknemers. Sverke et al. (2002) onderzochten dertig studies waarin de relatie tussen baanonzekerheid en betrokkenheid bij de organisatie werd onderzocht en acht studies waarin de relatie met vertrouwen in de organisatie werd onderzocht. Beide relaties waren negatief en significant. Baanonzekerheid hangt negatief samen met betrokkenheid bij de organisatie en vertrouwen in de organisatie (zie ook EASHW, 2007), hoewel deze relatie in longitudinaal onderzoek niet wordt ondersteund (Roskies et al., 1993; EASHW, 2007). Sverke et al. (2002) analyseerden in een meta-analyse 50 studies waarin de relatie tussen baanonzekerheid en tevredenheid met de functie werd onderzocht. Zij vonden ook voor deze relatie een hoog negatief en significant effect. Onderzoek wijst ook uit 
dat de angst om in de toekomst je baan te verliezen een significant effect heeft op de tevredenheid van werknemers met het werk (Theodossiou \& Vasileiou, 2007).

Daarnaast vonden Sverke et al. (2002) op basis van een meta-analyse van 37 surveys dat er een significant verband is tussen baanonzekerheid en mentale gezondheid. Hoe groter de baanonzekerheid, hoe slechter de mentale gezondheid. Deze relatie wordt ondersteund door longitudinaal onderzoek; ook de Whitehall II-studies laten een duidelijk verband zien tussen baanonzekerheid en (mentale) gezondheid. Vooral de angst je baan te verliezen bleek verband te houden met mentale gezondheid. De angst dat de inhoud van je baan verandert, was minder relevant. Het onderzoek laat zien dat baanonzekerheid een belangrijke stressor is, en zelfs dat het effect van deze stressor niet geheel verdwijnt als de bedreiging (van het verlies van de baan) is verdwenen (Sparks et al., 2001; Ferrie et al., 2004, 2005). In de Whitehall II-studies wordt ook de omgekeerde relatie onderzocht. In theorie is het mogelijk dat een slechte mentale gezondheid de baanzekerheid negatief beïnvloedt. Deze relatie bleek in het onderzoek van Ferrie et al. (2005) niet significant.

Sverke et al. (2002) onderzochten 19 studies waarin de relatie tussen baanonzekerheid en algemene (fysieke) gezondheid is onderzocht. Hoewel de relatie tussen baanonzekerheid en mentale gezondheid sterker is, is ook de relatie tussen baanonzekerheid en fysieke gezondheid significant. Een hogere baanonzekerheid hangt samen met een slechtere fysieke gezondheid en meer somatische klachten. Het onderzoek van Cheng (2005) onder Taiwanese werknemers ondersteunt deze resultaten. De relatie is echter niet onderzocht in longitudinale studies.

\section{Effecten van tijdelijke contracten op tevredenheid, welzijn en gezondheid}

Over het algemeen wordt gesteld dat werknemers met een tijdelijk contract een grotere baanonzekerheid ervaren dan werknemers met een vast contract (Lendfers \& Nijhuis, 1989; Klein Hesselink \& Van Vuuren, 1999; Sparks et al., 2001; Mauno \& Kinnunen, 2002; Cheng et al., 2005; De Cuyper \& De Witte, 2006; EASHW, 2007). Veel van de effecten van tijdelijke contracten op gezondheid en tevredenheid van werknemers lijken te worden verklaard door de hogere mate van baanonzekerheid. De relatie tussen tijdelijke contracten en tevredenheid en gezondheid van werknemers wordt echter niet alleen verklaard door de mate van baanonzekerheid die werknemers ervaren. In veel onderzoek wordt verondersteld dat de relatie tussen tijdelijke contracten en welzijn en gezondheid van werknemers ook verklaard kan worden uit het feit dat werknemers met een alternatief contract gemiddeld genomen slechtere arbeidsomstandigheden hebben dan werknemers met een vast contract (De Cuyper \& De Witte, 2006). Zo ervaren werknemers met een alternatief contract minder controle, minder taakautonomie, minder toegang tot training, een minder goed carrièreperspectief, minder informatie over arbeidsomstandigheden en gezondheids- en veiligheidszaken, minder veiligheidstrainingen, een hogere blootstelling aan gevaarlijke werkomstandigheden, meer ongelukken, meer repeterende en monotone taken en minder vaak een baan die de moeite waard is dan werknemers met een vast contract (EASHW, 2007; zie ook Goudswaard et al., 2000). Er zijn echter ook onderzoeken (De Cuyper \& De Witte, 2006) waarin vastgesteld wordt dat een aantal werkcondities voor tijdelijke werknemers beter is dan voor vaste werknemers. Juist door de aard van het contract worden minder hoge eisen 
gesteld aan tijdelijke werknemers, waardoor ze een lagere werkdruk ervaren dan vaste werknemers.

Verschillende onderzoeken laten zien dat werknemers met een tijdelijk contract een slechtere fysieke en mentale gezondheid hebben dan werknemers met een vast contract (Cleas et al., 2002; Benavides \& Benach, 1999), hoewel ook in onderzoek is aangetoond dat werknemers met een vast contract meer stress ervaren (Benavides \& Benach, 1999).

Op basis van de hiervoor beschreven onderzoeksresultaten veronderstellen wij dat tijdelijke contracten voor werknemers een grotere baanonzekerheid betekenen en een grotere baanonzekerheid samenhangt met een slechtere mentale en fysieke gezondheid van werknemers en minder tevredenheid van werknemers met hun werk en de organisatie.

\section{Het belang dat mensen hechten aan baanzekerheid}

In dit onderzoek is het belang dat mensen hechten aan baanzekerheid een centraal concept. In een aantal definities van baanonzekerheid wordt dit belang impliciet meegenomen. Hartley et al. (1991) stellen dat een respondent alleen baanonzekerheid ervaart als er sprake is van een discrepantie tussen het feitelijke niveau van baanonzekerheid en het gewenste niveau van baanonzekerheid. Het belang dat een werknemer hecht aan baanzekerheid wordt op deze manier impliciet gemeten als de ervaren baanonzekerheid wordt gemeten. Volgens ons is er echter een verschil tussen ervaren baanonzekerheid en het belang dat iemand aan baanzekerheid hecht. Het kan zijn dat iemand het gevoel heeft dat de kans dat hij zijn baan behoudt klein is en zich daar ook enige zorgen over maakt (ervaren baanonzekerheid), en dat hij tegelijkertijd niet veel belang hecht aan het behoud van de baan (bijvoorbeeld omdat hij snel verwacht een andere baan te vinden). Wij beschouwen baanonzekerheid dus als een apart concept.

Het feit dat werknemers met een tijdelijk contract meer baanonzekerheid ervaren, hoeft niet te betekenen dat zij ook meer belang hechten aan baanzekerheid. Het tegendeel lijkt soms zelfs waar. Werknemers met een vast contract 'hebben meer te verliezen' en kunnen vanuit dit grotere belang sterker reageren op baanonzekerheid (bijvoorbeeld als gevolg van reorganisaties) dan werknemers met een tijdelijk contract (Klein Hesselink \& Van Vuuren, 1999). Klein Hesselink \& Van Vuuren (1999) vinden in hun onderzoek een groep respondenten die een grote baanonzekerheid ervaart, maar ook de voorkeur geeft aan 'flexibiliteit' boven een vaste baan.

Klein Hesselink \& Van Vuuren (1999) veronderstellen dat de effecten van ervaren baanonzekerheid beïnvloed worden door het belang dat iemand hecht aan baanzekerheid. Zij halen hierbij het voorbeeld aan dat werknemers met een alternatief contract andere verwachtingen hebben ten aanzien van het voortduren van een baan, waardoor het effect van de ervaren baanonzekerheid minder sterk is voor deze groep.

Wat bepaalt nu het belang dat mensen hechten aan baanzekerheid? Eerder onderzoek toont aan dat er een samenhang is met de leeftijd van werknemers en de positie in een organisatie (Cleas et al., 2002). Wij verwachten daarnaast dat het feit of mensen verantwoordelijk zijn voor het inkomen (kostwinnerschap) en het opleidingsniveau het belang bepalen dat mensen hechten aan baanzekerheid. Zodra werknemers voldoende 
opgeleid (en dus employable) zijn, zal de zekerheid van een baan binnen een specifiek bedrijf voor hen van minder belang zijn.

\section{Verklaring voor de effecten van baanonzekerheid en de rol van het belang van baanzekerheid}

Gezondheid en welzijn van werknemers worden vaak verklaard vanuit het balansprincipe: als er een balans bestaat tussen inspanningen en beloning voelen mensen zich optimaal. Een veelgebruikte theorie in psychosociaal onderzoek is het Effort-RewardImbalance-model van Siegrist (1996). Het ERI-model veronderstelt dat inspanningen op het werk onderdeel zijn van een sociaal uitwisselingsproces. Tegenover inspanningen staan materiële en immateriële beloningen. Stressreacties ontstaan als een hoge inspanning gepaard gaat met een lage beloning Onder inspanning worden allerlei taakeisen gerekend, zoals tijdsdruk en fysieke inspanning. Onder beloning worden geld, waardering en carrièremogelijkheden verstaan, maar ook baanzekerheid. Het effect van baanonzekerheid op stress zou verklaard kunnen worden uit het feit dat baanonzekerheid 'negatief ' meeweegt in het schaaltje 'beloning' op de weegschaal tussen inspanning en beloning (zie ook Handaja \& De Witte, 2008). Tegenover deze negatieve beloning zou wellicht een positieve beloning (een tijdelijke, maar wel bijzonder interessante en uitdagende baan) kunnen staan, die het effect opheft. Het 'gewicht' van dit negatieve beloningsaspect kan per persoon verschillen. Baanonzekerheid kan zwaarder wegen voor mensen die baanzekerheid heel belangrijk vinden.

De theorie over zogenoemde 'psychologische contracten' kan eveneens een verklaring bieden waarom baanonzekerheid tot negatieve effecten kan leiden voor werknemers. Rousseau (1995) definieert een psychologisch contract als 'de individuele opvattingen met betrekking tot waargenomen wederzijdse verplichtingen, die ontstaan in de context van de relatie tussen werkgever en werknemer'. Een psychologisch contract kan geschonden of verbroken worden. Als dit eenzijdig gebeurt, lokt dit negatieve emoties bij de werknemer uit. Onderdeel van het psychologisch contract kan de verwachting zijn baanzekerheid te verkrijgen in ruil voor inspanning (De Witte \& Van Hecke, 2002). Als deze verwachting geschonden wordt en de werknemer dus baanonzekerheid ervaart, kan dit negatieve effecten hebben voor de werknemer. Als baanzekerheid echter geen verwachting is van de werknemer, bijvoorbeeld voor een werknemer met een tijdelijk contract, dan hoeft het gevoel van baanonzekerheid niet tot negatieve reacties te leiden. Met andere woorden: als werknemers niet zo veel belang hechten aan baanzekerheid, dan heeft ervaren baanonzekerheid mogelijk geen of minder negatieve effecten.

\section{Hypothesen en onderzoeksmodel}

De volgende hypothesen worden in dit onderzoek getoetst:

Hypothese 1: Het hebben van een tijdelijk contract leidt tot meer baanonzekerheid en daarmee tot een lagere tevredenheid met het werk en de organisatie, een lagere ervaren gezondheid en een grotere kans op burn-out.

In onderzoekstermen betekent dit dat de ervaren baanonzekerheid de relatie tussen een tijdelijk contract en de uitkomstvariabelen tevredenheid met het werk en de orga- 
nisatie, burn-out en gezondheid medieert, als gecontroleerd wordt voor de financiële positie in het bedrijf, autonomie, werkdruk en steun van chefs en collega's.

Daarnaast stellen wij een aantal hypothesen op met betrekking tot het belang van baanzekerheid voor werknemers:

Hypothese 2a: Het belang dat mensen hechten aan baanzekerheid wordt onder andere bepaald door de leeftijd, het opleidingsniveau en kostwinnerschap.

Hypothese 2b: Er is een verschil tussen het belang dat mensen hechten aan baanzekerheid en ervaren baanonzekerheid.

Hypothese 2c: Mensen die meer belang hechten aan baanzekerheid ervaren sterkere negatieve effecten van baanonzekerheid op tevredenheid met het werk en de organisatie, burn-out en gezondheid dan mensen die minder belang hechten aan baanzekerheid.

In onderzoekstermen schrijven we dat het belang dat mensen hechten aan baanzekerheid de relatie tussen ervaren baanonzekerheid en de uitkomstvariabelen tevredenheid met het werk en de organisatie, burn-out en gezondheid modereert.

Figuur 1 vat de hypothesen samen in een onderzoeksmodel.

\section{Figuur I Onderzoeksmodel}

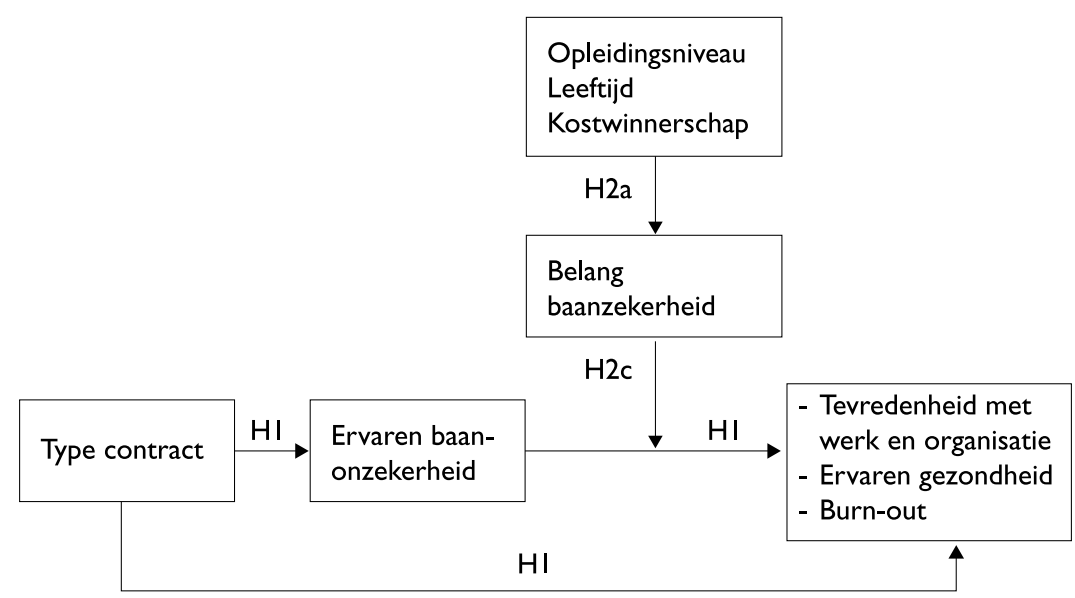

\section{Methode}

\section{Gebruik dataset en steekproef}

Dit onderzoek maakt gebruik van de TNO Arbeidssituatie Survey 2004 (TAS, zie Smulders, Andries \& Otten, 2001). De TAS is in 2000, 2002 en 2004 afgenomen bij een representatieve steekproef van de Nederlandse beroepsbevolking (werknemers en zelfstandigen). In 2004 is een aselecte steekproef getrokken van 10.698 werkenden, gestratificeerd naar geslacht, leeftijd, opleiding en regio. In 2004 heeft $54 \%$ van de 
netto steekproef de enquête op internet beantwoord. De uiteindelijke respons was in 2004 45\% ( $\mathrm{n}=4834)$. Met behulp van proportionele weging is gecorrigeerd voor de non-respons, zodanig dat de verdeling op geslacht, leeftijd, opleiding, stedelijkheidsgraad, en bedrijfstak representatief is voor de Nederlandse werknemers en zelfstandigen in het algemeen.

Alleen respondenten in de leeftijdscategorie $20 \mathrm{t} / \mathrm{m} 64$ jaar zijn meegenomen in de analyses. Van de totaal 4589 respondenten was $56 \%$ man en $44 \%$ vrouw. De meerderheid van de respondenten doet contractueel werk (48\%), 30\% heeft een 'witte boorden'beroep en $22 \%$ heeft een 'blauwe boorden'-beroep. Een kleine meerderheid van de populatie is kostwinner (65\%). De meerderheid van de respondenten heeft een opleiding op middelbaar niveau gevolgd (65,5\%), 29,1\% heeft een opleiding op hbo-niveau of hoger gevolgd en 5,3\% op lbo-niveau. 59,7\% werkt fulltime (35 uur of meer), 25,6\% werkt 20 t/m 34 uur en 14,7\% werkt minder dan 20 uur per week.

Een ruime meerderheid $(81,8 \%)$ van de respondenten heeft een vast contract. De overige groep heeft een tijdelijk contract met uitzicht op een vast contract $(6 \%, n=272)$, een tijdelijk contract $(6,8 \%, \mathrm{n}=311)$ of is zelfstandig ondernemer $(5,4 \%, \mathrm{n}=245)$.

\section{Vragenlijst}

De vragenlijst bevatte vragen over de persoon en het huishouden en over diverse aspecten van het werk. Smulders et al. (2001) geven een compleet overzicht van de vragenlijst in de TAS. In dit onderzoek wordt gebruikgemaakt van de concepten type contract, ervaren baanonzekerheid, ervaren belang baanzekerheid, tevredenheid met de organisatie en het werk.

Voor het bepalen van welk type contract mensen hebben, is gevraagd naar de aard van de werkkring. In het kader van het onderzoek worden vier contracttypen onderscheiden: werknemers met een vast dienstverband, werknemers met een tijdelijk dienstverband met uitzicht op vast en werknemers met een tijdelijk dienstverband (dienstverband voor bepaalde tijd, uitzendkrachten, oproepkrachten). Daarnaast is een groep zelfstandigen onderscheiden.

Ervaren baanonzekerheid is gemeten met een schaal gebaseerd op vier items: 'Is uw werkzekerheid goed?', 'Loopt u het risico om uw baan te verliezen?', 'Maakt u zich zorgen over het behoud van uw baan?' en 'Zijn uw toekomstmogelijkheden in uw bedrijf gunstig?'. De schaal loopt van 1 = lage baanonzekerheid tot 2 = maximale baanonzekerheid en heeft een Cronbach's alpha van 0.80. De schaal is ontleend aan Goudswaard et al. (1998).

Om na te gaan welk belang mensen hechten aan baanzekerheid is een item gebruikt dat onderdeel uitmaakt van een vraag naar wat respondenten het belangrijkst in een baan vinden. De vraagstelling was: kunt $\mathrm{u}$ aangeven welke aspecten $\mathrm{u}$ belangrijk en welke $\mathrm{u}$ minder belangrijk vindt bij het beoordelen van een baan in het algemeen? Met antwoordmogelijkheden: 1 = niet erg belangrijk tot 4 = heel erg belangrijk. De items zijn afgeleid uit de 'Motivator-Hygiene Two-factor Theory' van Herzberg et al. (1959). 
Voor het meten van de tevredenheid met de organisatie zijn twee stellingen voorgelegd aan de respondenten: 'Ik voel me uitstekend thuis in deze organisatie' en 'Vergeleken met de meeste andere bedrijven is het werken bij dit bedrijf erg aantrekkelijk'. De antwoordmogelijkheden lopen van 1 = helemaal mee oneens tot $5=$ helemaal mee eens. De vragen zijn samengevoegd tot een schaal en ontleend aan Goudswaard et al. (1998). De Cronbach's alpha van deze schaal is 0.82 .

Tevredenheid met het werk is gemeten met een vraag ontleend aan de vragenlijst Arbeid en Gezondheid (Gründemann et al., 1993). De vraag luidt: in welke mate bent u, alles bij elkaar genomen, tevreden met uw werk? De antwoordmogelijkheden zijn 1 = zeer ontevreden tot $5=$ zeer tevreden.

Burn-out is gemeten met vijf items van de Utrechtse Burnout Schaal (de UBOS, Schaufeli \& Van Dierendonck). Deze vijf items vormen de kerndimensie van deze lijst (emotionele uitputting). Gevraagd wordt of men zich mentaal uitgeput voelt door het werk, of men zich aan het einde van de werkdag 'leeg' voelt, of men zich al vermoeid voelt bij het opstaan, of men een hele dag werken een zware belasting vindt, en of men zich 'opgebrand' voelt door het werk. Mogelijke antwoorden liepen uiteen van 1 = nooit tot 7 = dagelijks (Cronbach's alpha $=0.90)$.

Algemeen ervaren gezondheid is nagegaan door te vragen wat men over het algemeen van zijn eigen gezondheid vond, met als antwoordmogelijkheden 'uitstekend', 'zeer goed', 'goed', 'matig' en 'slecht'.

De aspecten van de werksituatie: autonomie, werkdruk, steun van chefs, steun van collega's en de financiële positie van het bedrijf zijn als controlevariabelen meegenomen in de analyses.

Autonomie is gemeten met vijf items gebaseerd op het concept 'decision latitude' van Karasek. Hier wordt de variant van Goudswaard et al. (1998) gehanteerd die een uitbreiding is van de lijst die door Houtman et al. (1995) werd voorgesteld. Gevraagd wordt of men zelf kan beslissen hoe het werk wordt uitgevoerd, of men zelf de volgorde van werkzaamheden kan bepalen, of men zelf kan beslissen wanneer een taak uitgevoerd wordt, of de werkwijze wordt voorgeschreven, en of men een eigen werkwijze kan kiezen. Mogelijke antwoorden lopen uiteen van $1=$ nooit tot $4=$ altijd (Cronbach's alpha $=0.85$ ).

Werkdruk is gemeten met de schaal 'werkdruk' en 'taakeisen', die is ontleend aan de 'Job Content Questionnaire' ontwikkeld door Karasek et al. (1998). De vertaling is ontleend aan Houtman et al. (1998). Gevraagd wordt of men erg snel moet werken, of men heel veel werk moet doen, extra hard moet werken, of men te weinig tijd heeft om zijn of haar werk af te maken, en of het werk hectisch is. Antwoorden konden worden gegeven op een vierpuntschaal $(1=$ nooit $-4=$ altijd $)$. De Cronbach's alpha van deze schaal is 0.82 .

Steun van leidinggevende is gemeten met vier items ontleend aan het door Karasek ontwikkelde begrip 'supervisory support', vertaald door Houtman et al. (1995).

De schaal voor steun van collega's is ontleend aan het door Karasek ontwikkelde begrip 'coworker support' en vertaald door Houtman et al. (1995). Cronbach's alpha is in de 
groep onderzochte respondenten voor steun van chefs 0.86 en voor steun van collega's 0.80 .

De financiële positie van het bedrijf is nagegaan met de vraag: gaat het financieel goed met het bedrijf waarin u werkt? De antwoordmogelijkheden liepen van 1 = heel goed tot 5 = slecht. Deze vraag is ontleend aan Houtman et al. (1995).

Voor de volgende achtergrondkenmerken is eveneens gecontroleerd in de analyses: geslacht, leeftijd, opleiding, type beroep en contractomvang. Leeftijd is een continue variabele. Geslacht $(1=$ vrouw; $0=$ man $)$ en kostwinnerschap $(1=$ ja; $0=$ nee $)$ zijn dummy-variabelen. Evenals opleiding, waarbij een onderscheid is gemaakt tussen 'laag', 'middelbaar' en 'hoger' onderwijs, waarbij middelbaar onderwijs als referentiecategorie is gehanteerd. Type beroep is in het kader van het onderzoek 'ingedikt' tot drie hoofdgroepen:

1. agrarische, ambachtelijke, industriële beroepen en dergelijke. Hierin ligt het accent op manueel en/of technisch werk ('blauwe boord');

2. administratieve en andere 'kantoor'-beroepen. Hierin ligt het accent op niet-manueel, voornamelijk kantoorwerk ('witte boord');

3. beroepen in het onderwijs, de gezondheidszorg, in de handel en het verkeer en andere dienstverlenende beroepen die als gemeenschappelijk kenmerk hebben dat het 'contactuele' beroepen zijn, waarin men dus zeer direct heeft te maken met patiënten, leerlingen, klanten, passagiers en dergelijke.

De beroepsgroepen zijn als dummy-variabele gecodeerd, waarbij de 'contactuele beroepen' als referentiegroep zijn gebruikt. Contractomvang is eveneens een dummy-variabele, met de volgende categorieën: $\mathrm{t} / \mathrm{m} 19$ uur, 20 t/m 34 uur en meer dan 35 uur per week (= referentiecategorie).

\section{Analyses}

Voor het toetsen van het onderzoeksmodel is gebruikgemaakt van lineaire-regressieanalyse. De analyses zijn apart uitgevoerd voor de verschillende afhankelijke variabelen. In de eerste stap zijn de controlevariabelen (opleidingsniveau, leeftijd, geslacht, type beroep en contractomvang) en aspecten van de arbeidssituatie (zoals werkdruk, financiële positie van het bedrijf) ingevoerd. Vervolgens zijn de contracttypen toegevoegd. In de laatste stappen werden, indien van toepassing, ervaren baanonzekerheid, het belang dat mensen hechten aan baanzekerheid en de interactietermen ingevoerd.

Condities voor mediatie zijn dat: (a) de onafhankelijke variabele (type contract) een significante relatie vertoont met de mediator (ervaren baanonzekerheid); (b) de afhankelijke variabele (tevredenheid met de organisatie/werk, gezondheid en burn-out) een significante relatie vertoont met de onafhankelijke variabele (type contract); (c) dat de mediator (ervaren baanonzekerheid) een significante relatie vertoont met de uitkomstvariabelen. Een bewijs voor mediatie wordt geleverd als het contracttype een kleinere of niet significante relatie heeft met de uitkomstvariabelen als baanonzekerheid aan het model wordt toegevoegd (Baron \& Kenny, 1986).

Een conditie voor moderatie is dat de interactietermen significant samenhangen met de uitkomstvariabelen. Om de interactie-effecten nader te onderzoeken zijn een hoge 
en lage mate van het 'belang van baanzekerheid' onderscheiden door een splitsing te maken op basis van de mediaan.

\section{Resultaten}

\section{Mediatie door baanonzekerheid}

Voor het toetsen van onze eerste hypothese gaan we na of baanonzekerheid de relatie tussen tijdelijke contracten en de uitkomstvariabelen medieert. Een eerste voorwaarde voor mediatie is dat er een significante relatie is tussen de mediator (ervaren baanonzekerheid) en de onafhankelijke variabele (type contract). Tabel 1 toont de resultaten van de regressie-analyse met baanonzekerheid als afhankelijke variabele. Werknemers met een tijdelijk contract $(B=.24, \mathrm{p}<.01)$ en met een tijdelijk contract met uitzicht op een vast contract $(B=.12, \mathrm{p}<.01$ ) ervaren een significant hogere baanonzekerheid dan werknemers met een vast contract. Voor deze twee contracttypen wordt dus voldaan aan de eerste voorwaarde. In het navolgende worden de overige voorwaarden voor mediatie per afhankelijke variabele nagegaan.

Tabel I Hiërarchische regressie-analyse: baanonzekerheid $(\mathbf{N}=3356)$ (gestandaardiseerde regressiecoëfficiënten) ${ }^{\mathbf{a}}$

\begin{tabular}{lcc}
\hline Contractvormen & Stap I & Stap 2 \\
Tijdelijk met uitzicht op vast (vast = ref) & $* * 0,12$ & $* * 0,12$ \\
Tijdelijk (vast $=$ ref) & $* * 0,24$ & $* * 0,24$ \\
Zelfstandig (vast $=$ ref) & 0,02 & 0,02 \\
Belang baanzekerheid & & $* * 0,05$ \\
$\mathrm{R}^{2}$ adjusted & 0,19 & 0,19 \\
\hline
\end{tabular}

$* \mathrm{p}<.05 ; * * \mathrm{p}<.01$

${ }^{a}$ Alle coëfficiënten zijn gecorrigeerd voor leeftijd, geslacht, opleiding, beroep, contractomvang, autonomie, werkdruk, steun van chefs en collega's en financiële positie van het bedrijf.

In tabel 2 staan de resultaten van de regressie-analyse voor tevredenheid met het werk en de organisatie weergegeven.

Een tweede voorwaarde voor mediatie is dat het type contract een significante relatie vertoont met de afhankelijke variabele tevredenheid met de organisatie. Uit tabel 2 (stap 1) blijkt dat werknemers met een tijdelijk contract een significant lagere tevredenheid met de organisatie en het werk rapporteren dan werknemers met een vast contract (respectievelijk $\beta=-.06, p<.01$ en $\beta=-.09, p<.01$ ). De derde voorwaarde voor mediatie is dat er een significante relatie moet zijn tussen baanonzekerheid en tevredenheid met de organisatie en het werk (stap 2). Aan deze voorwaarde wordt ook voldaan. De associatie tussen baanonzekerheid en tevredenheid met het werk en de organisatie is negatief en significant. Uit stap 2 in de regressie-analyse blijkt dat mensen met een tijdelijk contract niet minder tevreden zijn met de organisatie als baanonzekerheid aan het model wordt toegevoegd dan mensen met een vast contract. Er is dus een aanwijzing dat baanonzekerheid de relatie tussen het type contract en tevredenheid met de organisatie medieert. Dit geldt niet voor tevredenheid met het werk. Als baanonzekerheid aan het model toegevoegd wordt, hebben werknemers met een tijdelijk contract nog steeds een significant lagere tevredenheid met het werk $(B=-.04, \mathrm{p}<$ 
.01), de 3 -waarde is echter wel minder laag. Er is dus een aanwijzing voor een gedeeltelijke mediatie door baanonzekerheid.

Tabel 2 Hiërarchische regressie-analyse: tevredenheid met de organisatie en het werk (gestandaardiseerde regressiecoëfficiënten) $^{\mathrm{a}}$

\begin{tabular}{|c|c|c|c|c|c|c|}
\hline & \multicolumn{3}{|c|}{$\begin{array}{l}\text { Tevredenheid organisatie } \\
(\mathbf{N}=3342)\end{array}$} & \multicolumn{3}{|c|}{$\begin{array}{l}\text { Tevredenheid werk } \\
(\mathbf{N}=3355)\end{array}$} \\
\hline & Stap I & Stap 2 & Stap 3 & Stap I & Stap 2 & Stap 3 \\
\hline \multicolumn{7}{|l|}{ Contractvormen } \\
\hline $\begin{array}{l}\text { Tijdelijk met uitzicht op vast (vast = } \\
\text { ref) }\end{array}$ & 0,00 & 0,02 & 0,02 & 0,01 & $* 0,04$ & $* 0,04$ \\
\hline Tijdelijk (vast $=$ ref) & $* *_{-} 0,06$ & $-0,02$ & $-0,02$ & $* *-0,09$ & $*_{-0,04}$ & $*_{-0,04}$ \\
\hline Zelfstandig (vast $=$ ref) & $-0,02$ & $-0,02$ & $-0,02$ & 0,00 & 0,00 & 0,00 \\
\hline \multicolumn{7}{|l|}{ Aspecten baanonzekerheid } \\
\hline Baanonzekerheid & & $*^{*}-0,16$ & $*_{-}-0,16$ & & $*_{-}-0,20$ & $* *_{-} 0,20$ \\
\hline Belang baanzekerheid & & & $* * 0,05$ & & & $-0,01$ \\
\hline $\mathrm{R}^{2}$ adjusted & 0,27 & 0,29 & 0,29 & 0,18 & 0,21 & 0,21 \\
\hline \multicolumn{7}{|l|}{ Stap 4 Interactieterm*** } \\
\hline $\begin{array}{l}\text { Belang baanzekerheid } \mathrm{x} \text { baanonzeker- } \\
\text { heid }\end{array}$ & & & $-0,13$ & & & 0,04 \\
\hline $\mathrm{R}^{2}$ adjusted & & & 0,29 & & & 0,21 \\
\hline
\end{tabular}

In tabel 3 staan de resultaten voor de uitkomstvariabelen burn-out en gezondheid vermeld.

Tabel 3 Hiërarchische regressie-analyse: burn-out en gezondheid (gestandaardiseerde regressiecoëfficiënten $)^{a}$

\begin{tabular}{|c|c|c|c|c|c|c|}
\hline & \multicolumn{3}{|c|}{ Burn-out (N = 3337) } & \multicolumn{3}{|c|}{ Gezondheid $(\mathbf{N}=\mathbf{3 3 3 8})$} \\
\hline & Stap I & Stap 2 & Stap 3 & Stap I & Stap 2 & Stap 3 \\
\hline \multicolumn{7}{|l|}{ Contractvormen } \\
\hline $\begin{array}{l}\text { Tijdelijk met uitzicht op vast (vast = } \\
\text { ref) }\end{array}$ & $* * 0,05$ & 0,03 & 0,03 & $* *_{-} 0,05$ & $*-0,04$ & $*_{-0,04}$ \\
\hline Tijdelijk (vast $=$ ref) & $* 0,04$ & 0,00 & 0,00 & $-0,02$ & 0,00 & 0,00 \\
\hline Zelfstandig (vast $=$ ref) & 0,01 & 0,01 & 0,01 & 0,00 & 0,00 & 0,00 \\
\hline \multicolumn{7}{|l|}{ Aspecten baanonzekerheid } \\
\hline Baanonzekerheid & & $* * 0,16$ & $* * 0,16$ & & $*_{-} *_{-}, 0,07$ & $*_{-}-0,07$ \\
\hline Belang baanzekerheid & & & 0,02 & & & $0,0 \mathrm{I}$ \\
\hline $\mathrm{R}^{2}$ adjusted & 0,20 & 0,22 & 0,22 & 0,04 & 0,04 & 0,04 \\
\hline \multicolumn{7}{|l|}{ Stap 4 Interactieterm*** } \\
\hline $\begin{array}{l}\text { Belang baanzekerheid } \mathrm{x} \text { baanonzeker- } \\
\text { heid }\end{array}$ & & & $* * 0,37$ & & & $-0,15$ \\
\hline $\mathrm{R}^{2}$ adjusted & & & 0,22 & & & 0,05 \\
\hline
\end{tabular}

$* \mathrm{p}<.05 ; *$ * $\mathrm{p}<.01$

*** Interactieterm is in een vierde stap toegevoegd, bijbehorende regressiecoëfficiënten staan niet weergegeven omdat deze niet gelijk met de hoofdeffecten zijn getoetst.

Alle coëfficiënten zijn gecorrigeerd voor leeftijd, geslacht, opleiding, beroep, contractomvang, autonomie, werkdruk, steun van leidinggevende en collega en financiële positie van het bedrijf. 
We bekijken eerst of werknemers met een tijdelijk contract meer burn-outklachten en een slechtere gezondheid rapporteren dan werknemers met een vast contract. Zowel werknemers met een tijdelijk contract als werknemers met een tijdelijk contract met uitzicht op vast rapporteren meer burn-outklachten dan werknemers met een vast contract (respectievelijk $\beta=.05, \mathrm{p}<.01, \beta=.04, \mathrm{p}<.01$ ) (stap 1). Wat betreft de gezondheid blijkt dat alleen werknemers met een tijdelijk contract met uitzicht op een vast contract een slechtere gezondheid ervaren dan werknemers met een vast contract $(ß=-.05, p<.01)$. In stap 2 in de regressieanalyse gaan we na of baanonzekerheid gerelateerd is aan meer burn-outklachten en een slechtere gezondheid. Er is een significant positieve relatie tussen baanonzekerheid en burn-outklachten $(\beta=.16, \mathrm{p}<.01)$ en er is ook een significant negatieve relatie tussen baanonzekerheid en ervaren gezondheid $(B=-.07, \mathrm{p}<.01)$. Tevens blijkt dat er sprake is van mediatie door baanonzekerheid voor werknemers met een tijdelijk contract en werknemers met een tijdelijk contract met uitzicht op een vast contract. Als baanonzekerheid aan het model toegevoegd wordt, hebben werknemers met een tijdelijk contract $(B=.00$, ns) en werknemers met een tijdelijk contract met uitzicht op vast $(\beta=.03$, ns) niet significant meer burn-outklachten dan werknemers met een vast contract. Voor de uitkomstvariabele gezondheid vinden we geen volledige mediatie. Als baanonzekerheid aan het model toegevoegd wordt, rapporteren werknemers met een tijdelijk contract met uitzicht op een vast contract nog steeds een significant lagere algemene gezondheid dan werknemers met een vast contract $(\beta=-.04, \mathrm{p}<.05)$; de $ß$-waarde is echter iets kleiner. Er is dus een aanwijzing voor gedeeltelijke mediatie.

Samengevat kan gesteld worden dat hypothese 1 voor het merendeel van de uitkomstvariabelen bevestigd wordt. De ervaren baanonzekerheid verklaart (voor een deel) de lagere tevredenheid met de organisatie en het werk voor mensen met een tijdelijk contract ten opzichte van mensen met een vast contract. Daarnaast verklaart de ervaren baanonzekerheid ook de negatieve effecten voor werknemers van een tijdelijk contract op burn-out.

\section{Het belang dat werknemers hechten aan baanzekerheid}

We veronderstelden dat het belang dat werknemers hechten aan baanzekerheid samenhangt met een aantal kenmerken, waaronder leeftijd, opleidingsniveau en kostwinnerschap (hypothese 2a). Uit de regressie-analyse (tabel 4) blijkt dat mensen met een lage opleiding significant meer belang hechten aan baanzekerheid en dat mensen met een hoge opleiding significant minder belang hechten aan baanzekerheid. Kostwinnerschap, het wel of niet verantwoordelijk zijn voor het hoofdinkomen, heeft geen significante relatie met het belang dat mensen hechten aan baanzekerheid. Ook leeftijd heeft geen significante relatie met het belang dat mensen hechten aan baanzekerheid. Hypothese 2a wordt dus alleen bevestigd voor opleidingsniveau en niet voor leeftijd en kostwinnerschap. 
Tabel 4 Hiërarchische regressie-analyse: het belang van baanzekerheid $(N=4233)$ (gestandaardiseerde regressiecoëfficiënten) ${ }^{\mathbf{a}}$

\begin{tabular}{lcc}
\hline Controlevariabelen & Stap I & Stap 2 \\
Opleiding laag (middelbaar = referentie) & $* * 0,04$ & $* * 0,05$ \\
Opleiding hoog (middelbaar = referentie) & $* *-0,30$ & $* *-0,29$ \\
Leeftijd (continu) & $-0,01$ & $-0,01$ \\
Kostwinnerschap (I = ja; 0 = nee) & 0,00 & 0,00 \\
Contractvormen & & 0,02 \\
Tijdelijk met uitzicht op vast (vast = ref) & & $* *-0,04$ \\
Tijdelijk (vast = ref) & & $* *-0,13$ \\
Zelfstandig (vast = ref) & 0,13 & 0,15 \\
$\mathrm{R}^{2}$ adjusted &
\end{tabular}

$* \mathrm{p}<.05 ; * * \mathrm{p}<.01$

a Alle coëfficiënten zijn gecorrigeerd voor geslacht, beroep en contractomvang.

Verder veronderstelden we dat er een verschil is tussen het belang dat werknemers hechten aan baanzekerheid en de ervaren baanonzekerheid (hypothese $2 \mathrm{~b}$ ). De Pearsoncorrelatie tussen baanonzekerheid en het belang van baanzekerheid is 0.003 ( $p$ >.05, niet significant). Hypothese $2 \mathrm{~b}$ wordt bevestigd, aangezien de correlatie niet significant is. Uit tabel 1 (stap 3 van de regressie-analyse) blijkt wel dat hoe meer belang mensen hechten aan baanzekerheid, hoe meer baanonzekerheid men ervaart als gecontroleerd wordt voor de achtergrondvariabelen.

In de laatste stap van de regressieanalyse met het ervaren belang van baanzekerheid als afhankelijke variabele zijn de contractvormen aan het regressiemodel toegevoegd (tabel 4). Opvallend is dat werknemers met een tijdelijk contract minder belang hechten aan baanzekerheid. Hiermee wordt aangetoond dat er een verschil is tussen 'ervaren baanonzekerheid' en het 'belang dat men hecht aan baanzekerheid'. Werknemers met een tijdelijk contract ervaren namelijk een hogere mate van baanonzekerheid, maar hechten hier minder belang aan.

Tot slot wordt hypothese $2 c$ getoetst, waarin verondersteld wordt dat mensen die meer belang hechten aan baanzekerheid sterkere negatieve effecten van baanonzekerheid op tevredenheid met het werk en de organisatie, burn-out en gezondheid ervaren dan mensen die minder belang hechten aan baanzekerheid. Voor het toetsen van deze hypothese is nagegaan of er een interactie-effect is tussen het belang dat mensen hechten aan baanzekerheid en de ervaren baanonzekerheid voor de verschillende uitkomstvariabelen. Dit is steeds de stap 4 in de regressiemodellen (tabellen 2 en 3 ). Het interactieeffect wordt alleen voor de uitkomstvariabele burn-out bevestigd ( $<$.01) (zie tabel $3)$. Vervolgens is de richting van het effect nagegaan. Hiertoe zijn twee aparte regressieanalyses uitgevoerd; voor mensen die veel belang hechten aan baanzekerheid (score 4) en mensen die weinig belang hechten aan baanzekerheid (score 3 of lager), waarbij gecontroleerd is voor de controlevariabelen. In beide analyses is het effect van baanonzekerheid op burn-out significant en positief. De $ß$ voor de groep die relatief veel belang hecht aan baanonzekerheid is echter hoger $(\beta=.19)$ dan de $\beta$ van de groep die relatief minder belang hecht aan baanzekerheid $(\beta=.12)$. Gesteld zou kunnen worden dat het belang dat mensen hechten aan baanzekerheid de relatie tussen baanonzekerheid en burn-out buffert. 


\section{Conclusie en discussie}

In de inleiding van dit artikel stelden we ons twee vragen. Ten eerste: hebben tijdelijke contracten een negatief effect op de tevredenheid, het welzijn en de gezondheid van werknemers? We veronderstelden dat dit het geval zou zijn, en dat deze negatieve effecten veroorzaakt zouden worden door de ervaren baanonzekerheid. We vonden inderdaad negatieve effecten van tijdelijke contracten op tevredenheid met de organisatie en het werk en burn-out. Voor de uitkomstvariabele tevredenheid met de organisatie en burn-out was er sprake van mediatie door baanonzekerheid. Dit laat dus zien dat baanonzekerheid een rol speelt in het verklaren van negatieve effecten van een tijdelijk contract. De relatie tussen het type contract en tevredenheid met het werk en gezondheid wordt echter niet geheel gemedieerd door baanonzekerheid. Naast ervaren baanonzekerheid zijn er dus ook andere factoren die maken dat werknemers met tijdelijke contracten minder tevreden zijn met hun werk en een minder goede gezondheid rapporteren dan werknemers met een vast contract. In de analyses is echter gecontroleerd voor een aantal werkkenmerken, waaronder autonomie, werkdruk en sociale steun. Mogelijk spelen bij de verklaring van tevredenheid met het werk en gezondheid andere aspecten van het werk een rol, zoals fysiek zwaar werk, toegang tot training en veiligheid. De relatie tussen contracttype en tevredenheid met het werk en de organisatie wordt ook vaak verklaard door te kijken naar het psychologisch contract dat werknemers hebben met de werkgever. Ontevredenheid met de organisatie en het werk wordt vooral veroorzaakt door 'contractbreuk', door een situatie waarin verwachtingen niet waargemaakt worden. Werknemers met een tijdelijk contract hebben wellicht minder hoge verwachtingen van de organisatie. Er zal minder snel sprake zijn van contractbreuk en dus ontevredenheid als gevolg daarvan. Werknemers met een tijdelijk contract hebben wellicht wel hogere verwachtingen van het werk zelf. Kenmerken van het werk spelen dus een grotere rol in hun psychologisch contract en mogelijk een grotere rol bij het verklaren van tevredenheid met het werk dan baanonzekerheid.

De tweede vraag die we ons stelden, luidde: veranderen negatieve effecten van baanonzekerheid als contractflexibiliteit meer 'gewoon' wordt? We veronderstelden dat 'het belang' dat mensen hechten aan baanzekerheid een belangrijke invloed heeft op de negatieve effecten van baanonzekerheid en dat, als dit belang verandert (er minder belang wordt gehecht aan baanzekerheid), de negatieve effecten ook minder zullen worden. We vonden inderdaad een bufferende werking van het belang dat mensen hechten aan baanzekerheid op de relatie tussen baanzekerheid en de uitkomstvariabele burn-out. Baanonzekerheid levert minder burn-outklachten op voor mensen die minder belang hechten aan baanzekerheid. Het negatieve effect van baanonzekerheid op de tevredenheid met de organisatie en het werk en ervaren gezondheid wordt echter niet afgezwakt als mensen minder belang hechten aan baanzekerheid. Het belang van baanzekerheid speelt kennelijk een minder grote rol bij het ervaren van tevredenheid met het werk, de organisatie en algemene gezondheid.

\section{Beperkingen van het onderzoek}

De schaal baanonzekerheid die in dit onderzoek gebruikt is, bevat ook een vraag over 'werkonzekerheid'. Werkonzekerheid betreft de onzekerheid over werk in het algemeen. In vervolgonderzoek is het nuttig om een onderscheid te maken tussen baanonzekerheid en werkonzekerheid, zeker als de effecten van 'onzekerheid' op tevredenheid met het 
werk en de organisatie en het welzijn en de gezondheid van werknemers onderzocht worden. In vervolgonderzoek zou om dezelfde reden een onderscheid moeten worden gemaakt tussen het belang dat men hecht aan baanzekerheid en aan werkzekerheid. Een andere beperking is dat wij onder de categorie 'tijdelijk contract' verschillende flexibele contractvormen hebben samengenomen: tijdelijke contracten, uitzendcontracten en oproepcontracten. Het is mogelijk dat de mate waarin deze groepen baanonzekerheid ervaren, verschilt. Voor verder onderzoek is het interessant dit onderscheid wel te maken. Voorts is het interessant een drieweg-interactie tussen contracttype, baanonzekerheid en het belang van baanzekerheid te onderzoeken. Op deze wijze kan worden nagegaan of baanonzekerheid dezelfde effecten heeft voor tijdelijke werknemers als voor vaste werknemer. Tevens kan zo worden onderzocht of het belang van baanzekerheid zowel voor vaste als voor tijdelijke werknemers een rol speelt in het bufferen van de effecten van baanonzekerheid.

De resultaten van dit onderzoek zijn gebaseerd op cross-sectioneel onderzoek. Op basis van dit onderzoek kunnen geen uitspraken gedaan worden over causaliteit. Dit zou wel kunnen op basis van een longitudinaal onderzoek. In de gebruikte dataset (TNO Arbeidssituatie Survey) zit een klein 'longitudinaal' deel bestaande uit 700 respondenten die in de jaren 2000, 2002, 2004 hebben meegedaan. De groep met een alternatief contract was echter te klein voor gedegen analyses. Bovendien is een belangrijk nadeel van longitudinaal onderzoek met als onafhankelijke variabele contractvormen dat de kans groot is dat deze variabelen veranderen in de tijd. Ook in andere onderzoeken is men tegen dit probleem aangelopen (EASHW, 2007). Daarom zal in een longitudinaal onderzoek gecontroleerd moeten worden voor wijzigingen in de contractvormen en controlevariabelen, waaronder de financiële positie van het bedrijf, aangezien deze variabelen een effect hebben op zowel de baanonzekerheid als de afhankelijke variabelen.

\section{Implicaties voor beleid}

In dit onderzoek wordt aangetoond dat baanonzekerheid negatieve gevolgen heeft voor werknemers en daarmee ook voor werkgevers. Voor mensen die weinig belang hechten aan baanzekerheid zijn de effecten minder groot. Het is daarom van belang interventies met name te richten op groepen werknemers die veel belang hechten aan zekerheid. Dit betreffen bijvoorbeeld werknemers met een vast contract en werknemers met een laag opleidingsniveau. Voor deze groepen werknemers zullen baanonzekerheid en werkonzekerheid wellicht dichter bij elkaar liggen dan voor werknemers met een hoge opleiding, die beter 'employable' zijn. Ook voor tijdelijke werknemers zal echter aandacht moeten zijn. Wij toonden immers aan dat voor deze groep negatieve uitkomsten (voor een deel) verklaard worden door baanonzekerheid.

Wij veronderstellen dat het vergroten van de employability van werknemers negatieve effecten van baanonzekerheid kan doen verlagen. Employability kan enerzijds worden gezien als een beloning of compensatie voor een onzekere baan, waardoor een stressvolle onbalans wordt voorkomen. Anderzijds kan het versterken van de employability mogelijk het belang verminderen dat mensen hechten aan baanzekerheid. Het vergroten van employability is tegengesteld aan de neiging van werkgevers om minder te investeren in 'tijdelijke' werknemers. Werkgevers zullen meer bereid moeten zijn te investeren in werknemers die wellicht deze investering bij een andere werkgever te gelde 
maken. Ook werknemers zelf zullen aandacht moeten besteden aan hun eigen employability. Niet iedereen zal daar even goed toe in staat zijn. De zwakkere groepen zullen daarbij ondersteund moeten worden.

\section{Literatuur}

ABU (2007). De toegevoegde waarde van uitzendwerk. Instroomonderzoek 2006. Ecorys: Badhoevedorp.

Ashford, S., Lee, C. \& Bobko, P. (1989). Content, causes, and consequences of job insecurity: a theory based measure and substantive test. Academy of Management Journal, 32, 803-829.

Bakhuys Roozeboom, M., De Vroome, E., Smulders, P., Van den Bossche, S. (2007). Trends in de arbeid in Nederland tussen 2000 en 2004. Hoofddorp: TNO Kwaliteit van Leven.

Baron, R.J. \& Kenny, D.A. (1986). The moderator-mediator variable distinction in social psychological research: Conceptual, strategic, and statistical considerations. Journal of Personality and Social Pscyhology, 51, 1173-1182.

Benavides F.G. \& Benach J. (1999). Precarious employment and health-related outcomes in the European Union. Dublin: European Foundation of Working and Living Conditions.

Boxall, P. \& Purcell, J. (2003). Strategy and Human Resource Management. Basingstoke: Palgrave MacMillan.

Cheng, Y., Chen, C.W., Chen, C.J. \& Chiang, T.L. (2005). Job insecurity and its association with health among employees in the Taiwanese general population. Social Science \& Medicine, 61, 41-52.

Cleas, R., De Witte, H., Schalk, R., Guest, D., Isaksson, K., Krausz, M., Mohr, G. \& Peiro, J.M. (2002). Het psychologisch contract van vaste en tijdelijke werknemers. Gedrag \& Organisatie, 15 (6), 436-455.

Cuyper, N. de \& Witte, H. de (2006). Autonomy and Workload Among Temporary Workers: Their effects on Job Satisfaction, Organizational Commitment, Life Satisfaction, and SelfRated Performance. International Journal of Stress Management, 13 (4), 441-459.

European Agency for Safety and Health at Work (EASHW) (2007). Expert forecast on emerging psychosocial risks related tot occupational safety and health. Luxembourg: EASHW.

Ferrie, J.E. (2004). Work, Stress and Health: Findings form the Whitehall II study. International Centre for Health and Society/ Department of Epidemiology and Public Health. University College London, UK.

Ferrie, J.E., Shipley, M.J., Newman, K., Stansfeld, S.A. \& Marmot, M. (2005). Self reported job insecurity and health in the Whitehall II study: potential explanations of the relationship. Social Science \& Medicine, 60, 1593-1602.

Goudswaard, A., Dhondt, S. \& Kraan, K. (1998). Flexibilisering en Arbeid in de Informatie-maatschappij; werknemersvragenlijst, bestemd voor werknemers van bedrijven die deelnemen aan het SZW-Werkgeverspanel 1998. Hoofddorp: TNO Arbeid.

Goudswaard, A., Kraan, K.O. \& Dhondt, S. (2000). Flexibiliteit in balans. Flexibilisering en de gevolgen voor werkgever en werknemer. Hoofddorp: TNO Arbeid.

Goudswaard, A., Leede, J. de, Hooff, M. van, Brugman, T., Klein Hesselink, J., Leeuw, M. de, Rhijn, G. van \& Gruyters, R. (2008). De toekomst van flexibele arbeid: hoe flexibel is Nederland? Hoofddorp: TNO.

Gründemann, R.W.M., Smulders, P.G.W. \& Winter, C.R. de (1993). VAG-Vragenlijst Arbeid en Gezondheid; Handleiding. Lisse: Swets Test Services.

Gucht, D. van \& Witte, H. de (2006). Over de samenhang tussen herstructureringen, baanonzekerheid en prestaties van werknemers. Tijdschrift voor Arbeidsvraagstukken, 22 (4), 362-376.

Handaja, Y. \& Witte, H. de (2008). Hangt baanonzekerheid samen met burn-out? Een exploratie in de bankensector. Tijdschrift voor Arbeidsvraagstuken, 24 (2), 148-166.

Hardarson, O. (2007). Men and women employed in fixed-term contracts involuntary. Eurostat: 98/ 2007.

Hartley, J., Jacobson, D., Klandermans, B. \& Vuuren, T. van (1991). Job insecurity: Coping with jobs at risk. London: Sage.

Herzberg, F., Mausner, B. \& Snyderman, B. (1959). The motivation to work. New York: Wiley.

Houtman, I., Goudswaard, A., Dhondt, S., Grinten, M. vander, Hildebrandt, V. \& Kompier, M. (1995). Evaluatie van de monitorstudie naar stress en lichamelijke belasting. Den Haag: VUGA. 
Houtman, I., Goudswaard, A., Dhondt, S., Grinten, M. van der, Hildebrandt, V. \& Poel, E.G.T. van der (1998). Dutch monitor on stress and physical load: risk factors, consequences, and preventive action. Occupational \& Environment Medicine, 55, 73-83.

Huiskamp, R. \& Schalk, R. (2002). Psychologische contracten in arbeidsrelaties: de stand van zaken in Nederland. Gedrag \& Organisatie, 15 (6), 370-385.

Jacobson, D. (1999). Toward a theoretical distinction between the stress components of the job insecurity and job loss experiences. Research in the Sociology of Organizations, 9, 1-19.

Karasek, R., Brisson, Ch., Kawakami, N., Houtman, I., Bongers, P. \& Amick, B. (1998). The Job Content Questionnaire (JCQ): an instrument for internationally Comparative Assessments of Psychosocial Job Characteristics. Journal of Occupational Health Psychology, 3, 322-355.

Kinnunen, U., Mauno, S., Nätti, J., Happonen, M. (1999). Perceived job insecurity: a longitudinal study among Finnish employees. European Journal of Work and Organizational Psychology, 8, 243-260.

Klein Hesselink, D.J. \& Vuuren, T. van (1999). Job flexibility and Job insecurity: The Dutch Case. European Journal of Work and Organizational Psychology, 8 (2), 273-293).

Lendfers, M.L.G.H. \& Nijhuis, F.J.N. (1989). Flexibilisering van de arbeid en gezondheidseffecten. OSA-werkdocument nr. W66.

Mauno, S. \& Kinnunen, U. (2002). Perceived job insecurity among dual-earner couples: Do its antecedents vary according to gender, economic sector and the measure used? Journal of occupational and Organizational Psychology, 75, 295- 314.

OECD (2007). <http://stats.oecd.org/wbos/default.aspx? >

Roskies, E., Louis-Guerin, C. \& Fournier, C. (1993). Coping with job insecurity: how does personality make a difference? Journal of organizational behaviour, 14, 617-630.

Rousseau, D.M. (1995). Psychological contracts in organization. Understanding written and unwritten agreements. Thousand Oaks, CA: Sage Publications.

Schaufeli, W. \& Dierendonck, D. van (zonder jaartal). UBOS-Utrechtse Burn-out Schaal. Handleiding. Utrecht: Universiteit van Utrecht.

Siegrist, J. (1996). Adverse health effects of high effort/low reward conditions. Journal of Occupational Health Psychology, 1, 27-41.

Smithson J. \& Lewis, S. (2000). Is job insecurity changing the psychological contract? Personnel Review, 29 (6), 680-702.

Smulders, P.G.W., Andries, F. \& Otten, F. (2001). Hoe denken Nederlanders over hun werk? Opzet, kwaliteit en eerste resultaten van de TNO Arbeidssituatie Survey. Hoofddorp: TNO Arbeid.

Sparks, K., Faragher, B. \& Cooper, C.L. (2001). Journal of Occupational and Organizational Psychology, 74, 489-509.

Strazdins, L., D’Souza, R.M., Lim, L.L.Y., Broom, D.H. \& Rodgers, B. (2004). Job Strain, Job insecurity, and Health: Rethinking the Relationship. Journal of Occupational Health Psychology, 9 (4), 296-305.

Sverke, J., Hellgren, J. \& Näswall, K. (2002). No Security: A Meta-Analysis and Review of Job insecurity and its Consequences. Journal of Occupational Health Psychology, 7 (3), 242-264.

Theodossiou, I. \& Vasileiou, E. (2007). Making the risk of job loss a way of life: Does it affect job satisfaction? Research in Economics, 61, 71-83.

Tucker, D. (2002). 'Precarious' Non-standard Employment-A review of the literature. Wellington: Labour Market Policy Group Department of Labour.

Witte, H. de \& Hecke, M. van (2002). Schending van het psychologisch contract, jobonzekerheid en arbeidstevredenheid. Gedrag en Organisatie, 15 (6), 484-501. 